\title{
PENGARUH INFERIORITY FEELING TERHADAP KECENDERUNGAN MELAKUKAN KEKERASAN DALAM BERPACARAN PADA DEWASA AWAL DI KARAWANG
}

\author{
Sinta Nopiyanti ${ }^{1}$, Nuram Mubina ${ }^{2}$, dan Marhisar Simatupang ${ }^{3}$ \\ Email:Sinta.nopiyanti@gmail.com
}

Fakultas Psikologi Universitas Buana Perjuangan Karawang

\begin{abstract}
Abstrak
Kecenderungan melakukan kekerasan dalam berpacaran bisa terjadi kepada siapapun, baik itu laki-laki maupun perempuan. Individu yang memiliki tingkat inferiority feeling tinggi tentu akan mempengaruhi bagaimana individu tersebut berperilaku dalam suatu hubungan. Bentuk dari kecenderungan kekerasan dalam berpacaran adalah kekerasan psikologis, kekerasan finansial, kekerasan seksual, dan kekerasan fisik. Tujuan dari penelitian ini adalah untuk mengetahui pengaruh inferiority feeling terhadap kecenderungan melakukan kekerasan dalam berpacaran pada dewasa awal di Karawang. Penelitian ini menggunakan metode penelitian kuantitatif dengan teknik sampling snowball dan kuota. Partisipan pada penelitian ini adalah dewasa awal berusia 18-40 tahun, berdomisili di Karawang dan menjalin suatu hubungan dengan pasangan. Jumlah partisipan dalam penelitian ini adalah sebanyak 647 orang, dengan jumlah partisipan laki-laki sebanyak 378, dan perempuan sebanyak 269. Metode pengumpulan data dilakukan dengan bantuan google form yang disebar melalui sosial media. Alat ukur yang digunakan dalam penelitian adalah the feeling of inadecuacy scale dengan jumlah aitem 38, dan skala kecenderungan kekerasan dalam berpacaran dengan jumlah aitem 66. Hasil penelitian menunjukkan bahwa inferiority feeling memiliki pengaruh sebanyak $28 \%$ terhadap kecenderungan melakukan kekerasan dalam dalam berpacaran pada dewasa awal di Karawang.
\end{abstract}

Kata kunci: Inferiority feeling, kecenderungan kekerasan dalam berpacaran, dewasa awal

\begin{abstract}
Dating violence tendency can happen to anyone, it can happen to male and female. Individuals who have a high level of inferiority feeling will certainly affect how the individual behaves in a relationship. Types of dating violence tendency are psychological violence, financial violence, sexual violence, and physical violence. The purpose of this study was to determine the effect of inferiority feeling on the tendency of dating violence in early adulthood in Karawang. This study uses quantitative research methods with snowball and quota sampling techniques. Participants in this study were early adults aged 18-40 years, residing in Karawang and in a relationship with a partner. The number of participants in this study was 647 people, with 378 male participants and 269 female participants. The data
\end{abstract}


collection method was carried out with the help of google form which was distributed through social media. The measuring instruments used in this research are the feeling of inadequacy scale with the number of items 38 , and the scale of the tendency of violence in dating with the number of items 66 . The results show that the inferiority feeling has an effect of $28 \%$ on the tendency to commit violence in dating in early adulthood in Karawang.

Keywords: Inferiority Feeling, Dating Violence, Early Adulthood

\section{PENGANTAR}

Perkembangan sosial pada masa dewasa awal merupakan masa puncak dalam bersosialisasi, individu dalam masa dewasa awal akan membangun hubungan] atau relasi yang lebih mendalam dan akrab pada berbagai macam lapisan pertemanan (Lybertha \& Desiningrum, 2016). Tugas perkembangan dewasa awal adalah menjalin hubungan intim (Papaplia \& Feldman, 2014). Dewasa awal merupakan masa permulaan dimana seseorang mulai menjalin hubungan secara intim dengan lawan jenisnya. Keinginan untuk membina hubungan yang akrab, intim dan penuh romantisme ini karena individu yang sedang berada dalam fase dewasa awal sedang berada dalam tahap pemenuhan kebutuhan akan intimasi (Agusdwitanti, Tambunan, \& Retnaningsih, 2015).

Apabila sepasang manusia berkomitmen untuk membina hubungan pernikahan pada akhirnya keduanya akan memulai suatu hubungan yang berlandaskan ketiga komponen diatas lewat fase pacaran (Papalia, Old \& Feldman, 2014). Pacaran merupakan sebuah upaya untuk saling mengenal antara pria dan wanita yang saling memiliki perasaan cinta antara satu sama lain, sebelum keduanya terikat dalam suatu ikatan pernikahan (Irfan \& Abidin , 2020). Masa berpacaran kerap kali diidentikan sebagai masa yang romantis dan menyenangkan. Pada masa ini, setiap pasangan akan mengalami kebahagiaan saling pengertian dan romantisme serta hal-hal yang sangat manis (Wiyanti, 2014). Romantisme dalam berpacaran membuat kebanyakan orang berpikir bahwa dalam hubungan berpacaran tidak mungkin terjadi kekerasan.

Dalam setiap hubungan pacaran pasti akan menghadapi fase-fase tingkat yang berkaitan dengan pasang surutnya suatu hubungan. Ada kalanya hubungan tersebut sedang mesra-mesranya ataupun sedang datar-datarnya, hingga kondisi yang paling tidak menyenangkan yaitu kondisi terpuruk. Hubungan berpacaran sering kali mengandung unsur buruk di dalamnya, seperti perilaku kekerasan dan perilaku menyimpang lainnya. Bentuk tindakan kekerasan dalam pacarana diantaranya kekerasan fisik, kekerasan psikologis, kekerasan finansial, dan kekerasan seksual (Adiswanisa \& Kristiana, 2015).

Fenomena kekerasan dalam pacaran merupakan salah satu kekerasan dalam ranah privat. Studi yang dirilis oleh Korean Institute of Criminology pada tahun 2017, didapatkan data bahwa sebanyak 1593 pria dan wanita melakukan kekerasan secara fisik dan psikologis kepada pasangannya. Kekerasan dalam pacaran tidak hanya terjadi di Korea, Kominisi Nasional Perempuan dalam Catatan Tahunan (CATAHU) di Indonesia mencatat pada tahun 2018 terdapat 1873 kasus, kemudian di tahun 2019 kasus kekerasan dalam pacaran meningkat menjadi 2073 kasus. Pelaku 
kekerasan dalam ranah personal atau privat biasanya pihak yang memiliki hubungan darah (seperti ayah, kakek, paman, kakak, adik), kekerabatan, perkawinan (suami/istri), maupun relasi intim (pacar) dengan korban.

Kasus kekerasan dalam berpacaran juga terjadi di kota Karawang khususnya pada mahasiswa. Dinas Pemberdayaan Perempuan dan Perlindungan Anak (DPPPA) kabupaten Karawang pada tahun 2019 mencatat ada 88 kasus kekerasan pada perempuan, beberapa diantaranya merupakan kasus kekerasan dalam pacaran.Keekerasan dalam berpacaran sebagai suatu tindakan yang disengaja untuk memaksa, menaklukan, mendominasi, mengendalikan, menguasai, menghancurkan secara fisik maupun psikologis (Adiswanisa \& Kristiana, 2015).

Kekerasan dalam berpacaran paling sering terjadi dan paling cepat diketahui adalah kekerasan fisik. Bentuk dari kekerasan fisik adalah segala perbuatan yang bertujuan untuk menyakiti individu, seperti: mecakar, menyiksa, menganiayaan, mendorong, meremas, menampar, dan kekerasan fisik lainnya (Adiswanisa \& Kristiana, 2015). Ada pula kekerasan psikologis yang bertujuan untuk menekan korban agar merasa lemah dan buruk, contohnya seperti perilaku mengancam, over protective, posesif, mengancam, dan intimidasi. Kekeraasan lainnya dapat berupa kekerasan finansial biasanya membatasi akses korban pada uang, contohnya memegang ATM korban, memaksa korban untuk membelikan segala sesuatu yang diinginkan pelaku, menggunakan uang korban dengan seenaknya. Terakhir adalah kekerasan seksual yang mencakup unsur seksualitas yang dilakukan tanpa persetujuan sehingga menimbulkan ketidaknyamanan, seperti, meraba tubuh korban, pemerkosaan, dan revenge porn(Adiswanisa \& Kristiana, 2015).

Salah satu faktor yang memepengaruhi kekerasan dalam berpacaran adalah inferiority feeling(WHO, 2014). Menurut Adler (dalam Yuniati, Andrianie, \& Sulistyawati, 2018) inferiority feeling adalah rasa minder atau rendah diri merupakan segala rasa kurang berharga yang timbul karena tidakmampuan psikologis atau sosial yang dirasa secara subyektif, ataupun karena keadaan jasmani yang kurang sempurna. Rasa kurang atau rasa rendah diri yang timbul karena perasaan kurang berharga atau kurang mampu dalam bidang penghidupan apa saja (Yuniati, Andrianie, \& Sulistyawati, 2018). Perasaan inferior sering terjadi tanpa disadari dan mampu membuat orang yang merasakannya melakukan kompensasi yang berlebihan untuk mengimbanginya, berupa prestasi yang spektakuler, atau perilaku antisosial yang ekstrem, maupun keduanya (Alwisol, 2019).

Kondisi orang-orang yang memiliki inferiority feeling akan melakukan berbagai upaya sebagai kompensasi sebagai usaha untuk mengatasi inferiority feeling yang dimilikinya. Kompensasi yang biasa dilakukan adalah membuat alasan, bersikap agresif dan menarik diri. Selain itu, pada umumnya individu dengan inferiority feeling menunjukkan suatu sikap dan perilaku peka atau tidak senang terhadap kritikan orang lain, sangat senang terhadap pujian atau penghargaan, senang mengkritik atau mencela orang lain, kurang senang berkompetisi, cenderung menyendiri, pemalu dan penakut (Yuniati, Andrianie, \& Sulistyawati, 2018).

Berdasarkan uraian di atas rumusan masalah yang dapat disusun adalah seberapa besar pengaruh inferiority feeling terhadap kecenderungan melakukan kekerasan dalam berpacaran pada dewasa awal di Karawang. Tujuan penelitian ini 
adalah untuk mengetahui seberapa besar pengaruh inferiority feeling terhadap kecenderungan melakukan kekerasan dalam berpacaran pada dewasa awal di Karawang.

\section{LANDASAN TEORI}

\section{a. Inferiority feeling}

Inferiority feeling merupakan perasaan dari diri kurang atau rasa rendah diri yang timbul karena perasaan kurang berharga atau kurang mampu dalam kehidupan sehari-hari. Menurut teori psikologi individual Adler, perasaan inferior muncul ketika seseorang tenggelam dalam rasa ketidakberdayaan atau mengalami suatu peristiwa yang membuat dirinya tidak mampu berbuat apa-apa (Suryabrata, 2019).

Inferiority feeling adalah konsep populer dari Alfred Adler dan menjadi dasar dalam psikologi individu, Inferiority feeling ada pada diri setiap individu tanpa terkecuali karena setiap manusia terlahir dengan inferiority feeling (merasa kurang mampu dan kurang kompeten) jika dibandingkan dengan orang dewasa Adler menyatakan bahwa setiap orang menderita inferioritas dalam bentuk yang berbeda-beda (Wahyudi, 2013). Inferiority feeling ditandai dengan adanya perasaan tidak kompeten atau kekurangmampuan diri.

Fleming dan Courtney (dalam Hariawan, 2016) ada lima aspek yang mewakili pengukuran inferiority feeling. Aspek dari inferiority feeling adalah social confidence, school abilities, self-regard, physical appearance, dan Physical Abilities. Faktor-faktor yang mempengaruhi inferiority feeling diantaranya ketidaksempurnaan fisik atau organ, pengamalan pada masa kanak-kanak, pola asuh orang tua, dan lingkungan sosial.

\section{b. Kecenderungan kekerasan dalam berpacaran}

Wolfe (dalam Ragil \& Margaretha, 2012) kecenderungan kekerasan dalam pacaran adalah kekerasan berpacaran sebagai segala usaha untuk mengontrol atau mendominasi pasangan secara fisik, seksual, atau psikologis yang mengakibatkan luka atau kerugian. Kekerasan dalam berpacaran diartikan sebagai suatu tindakan yang disengaja untuk memaksa, menaklukkan, mendominasi, mengendalikan, menguasai, menghancurkan, melalui cara- cara fisik, psikologis, ataupun gabungan-gabunganya, dan atau tindakan yang mungkin tidak disengaja, bukan intensional, tetapi disadari oleh ketidaktahuan, ketidakpedulian, atau alasan-alasan lain, yang menyebabkan subjek secara langsung atau tidak langsung terlibat dalam upaya pemaksaan (Arifin \& Rahmawati, 2015). Adapun hal-hal yang sering ditakuti oleh kebanyakan perempuan ketika menjalani hubungan pacaran, yaitu seperti pasangan terlalu posesif, terlalu mengekang, sering menaruh curiga, selalu mengatur apapun yang dilakukan, hingga mudah marah dan suka mengancam (Fadhilah, Arjawa, \& Mahadewi, 2019).

Murray (2014), menyatakan bahwa terdapat empat aspek kekerasan yang berpengaruh terhadap kekerasan dalam berpacaran yaitu, kekerasan psikologis, kekerasan finansial, kekerasan seksual, dan kekerasan fisik. World Health Organization (WHO) dalam World Report on Violence and Health (2014) 
mengindikasikan enam faktor yang menyebabkan kecenderungan kekerasan dalam berpacaran: faktor individual, sejarah kekerasan dalam keluarga, penggunaan alkohol, gangguan kepribadian, faktor dalam hubungan, faktor komunitas.

\section{METODE PENELITIAN}

Metode yang digunakan dalam penelitian ini adalah metode penelitian kuantitatif. Kerlinger dalam Sugiyono (2018) menjelaskan, penelitian kuantitatif adalah penelitian yang dilakukan pada populasi besar maupun kecil, data yang dianalisa adalah data dari sampel yang diambil dari populasi tersebut, untuk menemukan hubungan dan pengaruh antar variabel. Populasi dalam penelitian tidak diketahui, menurut Sugiyono (2018), populasi tidak diketahui disebut sebagai infinit. Populasi dalam penelitian ini adalah dewasa awal berusia 18 sampai 40 tahun dan menjalin hubungan dengan pasangannya (berpacaran, tunangan, kohabitasi, komitmen) selama satu tahun terakhir dan juga berdomisili di Karawang. Populasi tidak diketahui jumlahnya dikarenakan tidak ada data pasti berapa jumlah dewasa awal yang berpacaran di Karawang. Penelitian ini menggunakan teknik Nonprobability sampling dengan dua acara pengambilan sampel, yaitu snowball sampling dan sampling kuota.

Jumlah sampel dalam penelitian ini sejumlah 647 partisipan, dengan jumlah partisipan laki-laki sebanyak 378 orang, dan perempuan sebanyak 269 orang. Penelitian ini menggunakan dua alat ukur yaitu, the feeling of inadecuacy scale (untuk mengukur inferiority feeling) yang terdiri dari 38 aitem, dan skala kecenderungan kekerasan dalam berpacaran yang terdiri dari 66 aitem. Penyebaran skala dilakukan dengan cara disebar melalui sosial media (Instagram, Twitter, WhatsApp, Facebook, dan Telegram) dengan bantuan google form.

Analisis uji validitas dilakukan secara statistik dengan menggunakan teknik korelasi pearson correlation product moment dan uji reliabilitas dengan teknik alpha Cronbach. Uji hipotesis dilakukan dengan cara menggunakan analisis regresi sederhana.

\section{HASIL DAN PEMBAHASAN}

Analisis data dilakukan secara kuantitatif, untuk mengetahui apakah ada pengaruh antara inferiority feeling terhadap kecenderungan melakukan kekerasan dalam berpacaran pada dewasa awal di Karawang. 


\section{Tabel 1. Uji Regresi Sederhana}

\section{Coefficients $^{\mathrm{a}}$}

\begin{tabular}{|c|c|c|c|c|c|c|}
\hline \multicolumn{2}{|c|}{ Model } & \multicolumn{2}{|c|}{$\begin{array}{l}\text { Unstandardized } \\
\text { Coefficients }\end{array}$} & \begin{tabular}{|l} 
Standardized \\
Coefficients \\
Beta
\end{tabular} & $\mathrm{t}$ & Sig. \\
\hline 1 & (Constant) & 8.968 & .266 & & 33.722 & .000 \\
\hline & $\begin{array}{l}\text { Inferior } \\
\text { Feeling }\end{array}$ & .356 & .020 & .290 & 7.684 & .000 \\
\hline
\end{tabular}

a. Dependent Variable: SKP (Kecenderungan Kekerasan Dalam Berpacaran)

Hasil uji determinasi pada $R$ square sebesar 0.284 menunjukkan bahwa variabel inferioriority feeling berpengaruh sebanyak $28 \%$ terhadap variabel kecenderungan kekerasan dalam berpacaran. Sedangkan sisanya $72 \%$ dipengaruhi oleh variabel lain. Persamaan fungsi regresi sederhana pada penelitian ini adalah :

$$
\mathrm{Y}=8.968+0.356
$$

Maka pada kondisi yang tetap sebesar 8.968 menunjukkan apabila tidak ada pengaruh pada inferiority feeling maka nilai konsisten kecenderungan kekerasan dalam berpacaran akan meningkat sebanyak 0.356. Kesimpulan dari nilai konstanta yang positif menunjukkan bahwa variabel inferiority feeling berpengaruh secara positif terhadap variabel kecenderungan kekerasan dalam berpacaran.

Berdasarkan pada hasil pengolahan data melalui uji regresi sederhana selaras dengan praduga jawaban sementara $(\mathrm{Ha})$ yang menyatakan adanya pengaruh inferiority feeling terhadap kecenderungan kekerasan dalam pacaran, dan bertolak belakang dengan hipotesis null (H0). Dengan demikian, dapat disimpulkan bahwa Ha diterima dan $\mathrm{H} 0$ ditolak.

Hasil penyebaran data pada 647 partisipan menggunakan kuesioner yang disusun berdasarkan dua alat ukur yang diadaptasi dan direkonstruksi ulang yaitu, skala the feeling of inadecuacy(untuk mengukur inferiority feeling) dan skala kecenderungan kekerasan dalam berpacaran. Hasil dari data partisipan dikategorisasikan menjadi empat kategori. Kategori ini dihitung menggunakan standar deviasi, satuan mean dan nilai hitung responden (X) dengan bantuan SPSS versi 24 for macbook. Berikut adalah hasil dari masing-masing kategorisasi variabel:

Tabel 2. kategorisasi inferiority feeling

\begin{tabular}{lll}
\hline Kategori & Jumlah & Presentasi \\
\hline Sangat Rendah & 18 & $2.8 \%$ \\
\hline Rendah & 289 & $44.7 \%$ \\
\hline Tinggi & 334 & $51.6 \%$ \\
\hline Sangat Tinggi & 6 & $0.9 \%$ \\
\hline Total & 647 & $100 \%$ \\
\hline
\end{tabular}


Berdasarkan tabel di atas, partisipan dengan kategori inferiority feeling sangat rendah sebanyak 2.8\%, partisipan dengan kategori rendah sebanyak $44.7 \%$, partisipan dengan kategori tinggi sebanyak $51.6 \%$, dan partisipan dengan kategori sangat tinggi sebanyak $0.9 \%$.

Pada variabel kecenderungan kekerasan dalam berpacaran dikategorisasikankedalam empat ketegori, maka didapatkan hasil distribusi skor partisipan pada tabel di bawah ini :

Tabel 3. Kategorisasi kecenderungan kekerasan dalam berpacaran

\begin{tabular}{lll}
\hline Kategorisasi & Jumlah & Presentasi \\
\hline Sangat Rendah & 2 & $0.3 \%$ \\
\hline Rendah & 343 & $53.0 \%$ \\
\hline Tinggi & 276 & $42.7 \%$ \\
\hline Sangat Tinggi & 26 & $4.0 \%$ \\
\hline Total & 647 & $100.0 \%$ \\
\hline
\end{tabular}

Berdasarkan tabel di atas, partisipan dengan kategori kecenderungan kekerasan dalam berpacaran sangat rendah sebanyak $0.3 \%$, partisipan dengan kategori kecenderungan kekerasan dalam berpacaran sangat rendah sebanyak $53.0 \%$, partisipan dengan kategori kecenderungan kekerasan dalam berpacaran tinggi sebanyak 42.7\%, partisipan dengan kategori kecenderungan kekerasan dalam berpacaran sangat tinggi sebanyak $4.0 \%$.

Hal ini sesuai dengan hasil penelitian sebelumnya yang dilakukan oleh Acharya (2015), dalam penelitian tersebut di temukan bahwa pada subjek dewasa awal usia 18-25 inferiority feeling menjadi salah satu penyebab dalam melakukan kekerasan dalam berpacaran. Penelitian lainnya yang dilakukan oleh Wahyudi (2013), menunjukkan bahwa terdapat hubungan yang tinggi antara inferiority feeling dengan agresivitas untuk melakukan kekerasan. Hal tersebut dikarenakan subjek mencoba mengkompensasikan inferiority feeling miliknya menjadi superioriy dengan cara melakukan kekerasan.

Smith, dkk., (1999), seperti yang dikutip oleh Wahyudi (2013) yang mendukung teori Adler, agresivitas untuk melakukan kekerasan ini terjadi karena seseorang yang melakukan tindakan kekerasan dimaksudkan sebagai salah satu upaya untuk mencapai tujuan hidupnya yaitu menuju superioritas. Salah satu contoh bahwa inferiority feeling berpengaruh terhadap munculnya agresivitas dalam diri seseorang yakni dalam bentuk kekerasan terhadap pasangan. Perilaku kecenderungan kekerasan dalam berpacaran didasari adanya kecemasan dan inferiority feeling. Dengan melakukan kekerasan kepada pasangan, seseorang dengan inferiority feeling tinggi merasa merasa bahwa dirinya adalah seorang jagoan yang dapat mengontrol keadaan, sehingga berusaha untuk menaikkan harga dirinya. Seseorang yang melakukan kecenderungan kekerasan dalam berpacaran memiliki hasrat superioritas yang merupakan sebuah topeng untuk menutupi ketidakmampuan dirinya. Hal tersebut menyebabkan seseorang yang memiliki inferiority feeling tinggi melukai seseorang yang dianggap lemah agar dirinya terlihat lebih unggul unggul. 
Analisis data tambahan antara inferiority feeling dengan data demografi menunjukkan bahwa partisipan dengan tingkat inferiority feeling tinggi terjadi pada partisipan dengan jenis kelamin laki-laki. Jika dilihat dari rentang usia partisipan dengan tingkat inferiority feeling tinggi berada pada rentang usia 21-25 tahun. Partisipan dengan tingkat inferiority feeling tinggi berada pada pekrjaan sebagai karyawan. Sedangkan tingkat pendidikan terakhir partisipan dengan tingkat inferiority feeling tinggi terjadi pada tingkat pendidikan SLTA sederajat. Kemudian partisipan dengan tingkat inferiority feeling yang menjalin hubungan pacaran, dan terakhir partisipan dengan tingkat inferiority feeling tinggi dengan lama menjalin hubungan selama lebih dari 4 tahun.

Analisis data berdasarkan pada jenis kelamin dengan inferiority feeling pada dewasa awal di Karawang menunjukkan bahwa laki-laki memiliki tingkat inferiority feeling yang tinggi dibandingkan perempuan. Pada analisa usia dengan inferiority feeling menunjukkan rentang usia tertinggi ada pada 21-25 tahun. Hal tersebut sesuai dengan penelitian yang dilakukan oleh Yulia (2017) yang menyebutkan bahwa lakilaki usia 21-25 tahun memiliki inferiority feeling yang cukup tinggi.

Analisis data berdasarkan pendidikan terakhir dengan inferiority feeling menunjukkan bahwa SLTA Sederajat memiliki inferirority feeling tinggi, kemudian mahasiswa, lalu lainnya, serta wirausaha, dan terakhir mahasiswa pekerja/wirausaha. Pada analisis data pekerjaan dengan inferiority feeling menunjukkan bahwa karyawan memiliki inferiority feeling paling tinggi, kemudian, mahasiswa, lalu lainnya, serta wirausaha, dan terakhir mahasiswa pekerja/wirausaha. Hasil analisis data ini sesuai dengan penelitian yang dilakukan oleh Hirao (2014) bahwa inferiority feeling tinggi terjadi pada mahasiswa.

Analisis data berdasarkan status hubungan dengan inferiority feeling menunjukkan bahwa pacaran memiliki tingkat inferiority feeling paling tinggi, kemudian komitmen, lalu tunangan, dan terakhir kohabitasi. Pada analisis data lama menjalin hubungan dengan inferiority feeling menunjukkan bahwa $>4$ tahun (lebih dari empat tahun) memiliki tingkat inferiority feeling paling tinggi, kemudian 1 tahun, lalu $<1$ tahun (kurang dari satu tahun), serta 2 tahun, dan terakhir 3 tahun. Hasil analisis data ini sesuai dengan hasil penelitian yang dilakukan oleh (Xiaoying, Ernest, \& Siqing (2018) yang menunjukkan bahwa lama hubungan berpacaran akan menunjukkan inferiority feeling.

Analisis data tambahan antara kecenderungan melakukan kekerasan dalam pacaran dengan data demografi menunjukkan bahwa partisipan dengan tingkat kecenderungan kekerasan dalam berpacaran tinggi didominasi oleh laki-laki, sedangkan berdasarkan pada usia ada pada rentang 21-25 tahun. Jika berdasarkan pada pendidikan terakhir, partisipan dengan tingkat kecenderungan kekerasan dalam berpacaran tinggi berada pada SLTA sederajat. Partisipan dengan tingkat kecenderungan kekerasan dalam berpacaran yang tinggi berada pada pekerjaan sebagai karyawan. Kemudian status hubungan dengan tingkat kecenderungan kekerasan dalam berpacaran tinggi pada pacaran, selain itu lama menjalin hubungan partisipan berpengaruh dengan tingkat kecenderungan kekerasan dalam berpacaran tertinggi berada pada lebih dari empat tahun. 
Analisis data berdasarkan pada jenis kelamin dengan kecenderungan kekerasan dalam berpacaran pada dewasa awal di Karawang menunjukkan bahwa, laki-laki memiliki tingkat tinggi dalam kecenderungan melakukan kekerasan dalam berpacaran dibandingkan perempuan. Pada analisa usia dengan kecenderungan kekerasan dalam berpacaran menunjukkan bahwa rentang usia terbanyak kecenderungan melakukan kekerasan dalam berpacaran adalah 21-25 tahun. Hasil analisis data ini sesuai dengan penelitian sebelumnya yang dilakukan oleh Christina, dkk., pada tahun (2015) yang menunjukkan bahwa laki-laki memiliki tingkat kecenderungan melakukan kekerasan dalam berpacaran lebih tinggi dibanding perempuan, serta rentang usia 21-25 tahun adalah rentang usia terbanyak dalam melakukan kecenderungan kekerasan dalam berpacaran.

Analisis data berdasarkan pada pendidikan terakhir menunjukkan bahwa SLTA Sederajat menunjukkan angka tertinggi dalam melakukan kecenderungan kekerasan dalam berpacaran, disusul dengan S1, Mahasiswa, Diploma, dan S2. Pada analisa berdasarkan pekerjaan partisipan dalam melakukan kecenderungan kekerasan dalam berpacaran, Karyawan menunjukkan angka tertinggi sebanyak 230 partisipan, Mahasiswa, kemudian Lainnya, lalu Mahasiswa, dan yang terakhir Mahasiswa pekerja/wirausaha. Hal ini sesuai sesuai dengan hasil penelitian yang dilakukan oleh Sari pada tahun (2018) yang menunjukkan bahwa mahasiswa memiliki kecenderungan untuk melakukan kekerasan dalam hubungan pacaran.

Pada analisa status hubungan dalam melakukan kecenderungan kekerasan dalam berpacaran, Pacaran menunjukkan angka tertingi sebanyak 475 partisipan, kemudian komitmen, lalu tunangan, dan terakhir kohabitasi. Lama menjalin hubungan yang berpengaruh dalam melakukan kecenderungan dalam berpacaran menunjukkan bahwa $>4$ tahun (lebih dari 4 tahun) adalah angka tertinggi, kemudian 1 tahun, lalu <1 tahun (kurang dari 1 tahun), serta 2 tahun, dan terakhir 3 tahun. Hal ini sesuai degan penelitian sebelumnya yang dilakukan oleh Adiningsih, Dannisworo, dan Christia (2020), yang menunjukkan bahwa pasangan yang menjalin hubungan berpacaran selama lebih dari empat tahun memiliki kecenderungan kekerasan dalam berpacaran.

\section{KESIMPULAN}

Setelah melakukan penelitian dan analisis data maka diperoleh kesimpulan bahwa adanya pengaruh antara inferiority feeling terhadap kecenderungan kekerasan dalam berpacaran pada dewasa awal di Karawang. Jenis kelamin, usia, status hubungan, pendidikan terakhir, pekerjaan, dan lama menjalin hubungan juga memiliki pengaruh terhadap individudengan inferiority feeling dan individu dengan kecenderungan melakukan kekerasan dalam berpacaran.

\section{DAFTAR PUSTAKA}

Adiningsih, H., Dannisworo, C., \& Christia, M. (2020). Dating violence perpetration: masculine ideology and masculine gender role stress as predictors. Humanitas Indonesian Psychological Journal, 17(1), 12-22. 
Adiswanisa, L., \& Kristiana, I. (2015). Hubungan antara secure attachment dengan kecenderungan melakukan kekerasan dalam pacaran pada mahasiswa teknik mesin dan teknik geologi Universitas Diponegoro Semarang. Empati, 3(3).

Agusdwitanti, H., Tambunan, S., \& Retnaningsih. (2015). Kelekatan dan intimasi pada dewasa awal. Jurnal Psikologi, 8(1), 18-24.

Alwisol. (2019). Psikologi kepribadian. Malang: UMM Press.

Arifin, S., \&Rahmawati, A. (2015). Tindak kekerasan mahasiswa terhadap pacar dalam relasi multi-partner. Ilmu Kesejahteraan Sosial Universitas Jember, 114.

Christina, D., Katie, E., Erika, K., \& Christine, G. (2015). Perceptions of dating violence and associated correlates: A study of college young adults. Journal of Interpersonal Violence 1-27, 1-27.

Fadhilah, E., Arjawa, I., \& Mahadewi, N. (2019). Perilaku posesif dalam gaya berpacaran di kalangan remaja kota Denpasar. Jurnal Ilmiah Sosiologi (Sorot), 1(2).

Hariawan, S. (2016). Hubungan antara kontrol diri (self-control) dan perasaan rendah diri (inferiority feeling) dengan kecenderungan agresi pada remaja.

Hirao, K. (2014). Comparison of feelings of inferiority among university students with autotelic, average, and nonautotelic personalities. Nort America Journal Medical Science.

Irfan, M., \& Abidin , Z. (2020). Perjalanan cintaku: Sebuah studifenomenologis tentang pengalaman pencarian jodoh pada pria pengguna aplikasi ta'arufonline Indonesia. Junal Empati, 8 (3).

Karawang, D. P. (2020, 08 24). Pemerintah Kabupaten Karawang Prop. Jawa Barat Indonesia. Retrieved From Jumlah Kasus Kekerasan Terhadap Perempuan Dan Anak Cenderung Meningkat: Https://Www.Karawangkab.Go.Id/Berita/Jumlah-Kasus-KekerasanTerhadap-Perempuan-Dan-Anak-Cenderung-Meningkat-0

Lybertha, D., \&Desiningrum, D. (2016). Kematangan emosi dan persepsi terhadap pernikahan pada dewasa awal: studi korelasi pada mahasiswa fakultas hukum Universitas Diponegoro. Jurnal Empati, 5(1).

Murray, J. (2014). But I Love Him (Protecting Your Daughter From Controlling, Abusive Dating Relationship). Jakarta: Gramedia.

Papaplia, D., \& Feldman, R. (2014). Menyelami Perkembangan Manusia (Experience Human Development) Edisi 12 Buku 2. Jakarta: Penerbit Salemba Humanika.

Perempuan 2019. Retrieved From Www.Komnasperempuan.Go.Id: Https://Www.Komnasperempuan.Go.Id/Read-News-Siaran-Pers-CatatanTahunan-Catahu-Komnas-Perempuan-2019\%20

Perempuan), K. N. (2019, 3 7). Catatan Tahunan (Catahu) Komnas Perempuan Tahun 2018. Retrieved From Www.Komnasperempuan.Go.Id: 
Https://Www.Komnasperempuan.Go.Id/File/Pdf_File/2018/Siaran\%20pers\% 202018/Lembar\%20fakta\%20catahu\%207\%20maret\%202018.Pdf

Ragil, N., \&Margaretha. (2012). Pengaruh gaya kelekatan romantis dewasa (adult romantic attachment style) terhadap kecenderungan untuk melakukan kekerasan dalam pacaran. Jurnal Psikologi Kepribadian Dan Sosial, 01(02).

Santrock, J. (2012). Life-spandevelopment edisi 13 jilid 2. Jakarta: Penerbit Erlangga.

Sari, I. P. (2018). Kekerasan dalam hubungan pacaran di kalangan mahasiswa: studi refleksi pengalaman perempuan. Jurnal Dimensia, 7(1), 64-85.

Sugiyono. (2018). Metode Penelitian Kuantitif. Bandung: Penerbit Alfabeta.

Suryabrata, S. (2019). Psikologi Kepribadian. Jakarta: Raja Grafindo Persada.

Wahyudi, R. A. (2013). Hubungan antara inferiority feeling dan agresivitas pada remaja delinkuen (studi di PSMP Antasena Magelang). Developmental and Clinical Psychology I, 1-5.

Who. (2014). Worrld Health Organization : Global Status Report On Violence Prevention 2014 . Retrieved From Who.Int: Https://Www.Who.Int/Violence_Injury_Prevention/Violence/Status_Report/2 014/En/

Wiyanti, R. H. (2014). Persepsi Siswa Tentang Perilaku Sosial Dalam Pacaran (Studi Kasus Siswa Sma Al Islam 1 Surakarta). Sosialitas Jurnal Ilmiah Pendidikan Sosiologi Antropologi.

Xiaoying, Z., Ernest, B., \&Siqing, P. (2018). Feeling inferior, showing off: the effect of nonmaterial social comparisons on conspicuous consumption. Journal of Business Research, 196-208.

Young-Oh, H., Seong-Jin, Y., \& Seung Hee, J. (2020, 08 23). Korean Institute Of Criminology : Research Report. Retrieved From Eng.Kic.Re.Kr: Https://Eng.Kic.Re.Kr/Brdartcl/Boardarticleview.Do?Brd_Id=Bdidx_736t9s8 7rydqxzpmkp5987\&Cont_Idx=797\&Srch_Menu_Nix=W5mg0hj7\&Edomwe $\underline{\text { ivg } p=R \& S r c h \_M u \_L a n g=C d i d x 00023}$

Yulia, D. (2017). Prinsip individual adler pada atlet tuna daksa di kota Tenggarong Kabupaten Kutai Kartanegara. Psikoborneo, 843-853.

Yuniati, R., Andrianie, P., \& Sulistyawati, D. (2018). Efektivitas penanaman lima watak utama untuk mengatasi in ferioritas pada tuna daksa. Jurnal Psikologi Ilmiah. 